\title{
The effect of L-cysteine on appetite in humans
}

\author{
Amin A, Agahi A, Martin NM, Ghatei MA, Bloom SR \& Murphy KG \\ Section of Investigative Medicine, Imperial College London, London, UK
}

\section{Background}

-High protein diets suppress appetite and facilitate weight loss, but are difficult to adhere to ${ }^{1-3}$

- Understanding mechanisms by which protein suppresses appetite may establish targets for more acceptable interventions to treat or prevent obesity.

-The amino acid products of protein digestion may be sensed to drive satiety.

-Amino acid sensing receptors (CaR, T1R1/T1R3 and GPRC6A) identified. -Previous work has investigated the effect of specific amino acids acting as ligands for these receptors on food intake in rodents.

-L-cysteine activates all 3 receptors ${ }^{4-6}$.

-Diets rich in whey protein (containing high levels of L-cysteine):

More satiating ${ }^{7}$

Suppress circulating levels of the orexigenic hormone ghrelin to a greater extent, than other types of protein 8

- Pilot studies suggested L-cysteine can reduce food intake in rodents, and that this effect is at least partly mediated by a reduction in circulating ghrelin levels.

\section{Hypothesis and Aim}

\section{Hypothesis}

- L-Cysteine can suppress appetite in humans.

Aim

- To determine subjective measures of appetite using visual analogue scales (VAS) following a dose of L-cysteine

\section{Methods}

\section{Study participants:}

- Healthy male ( $n=2,1$ Caucasian, 1 South Asian) and female ( $n=5$, all Caucasian) subjects with a mean $( \pm S D)$ age of $35.9 \pm 10.9$ years and BMI of $23.7 \pm 4.3 \mathrm{~kg} / \mathrm{m}^{2}$ who were weight stable for the 3 months before recruitment

\section{Study design:}

-Participants were studied in a single-blinded crossover fashion. They received one of the following at each study visit: cysteine $0.07 \mathrm{~g} / \mathrm{kg}$, glycine $0.07 \mathrm{~g} / \mathrm{kg}$ or vehicle. Glycine was used as a negative control as it was found not to reduce food intake in rodent models. Blood samples for gut hormone analysis and VAS for assessment of hunger and fullness were collected at 15 min intervals starting at $\mathrm{t}=-15 \mathrm{~min}$ for $2.5 \mathrm{hrs}$ after dosing.

\section{L-cysteine suppresses ghrelin release}

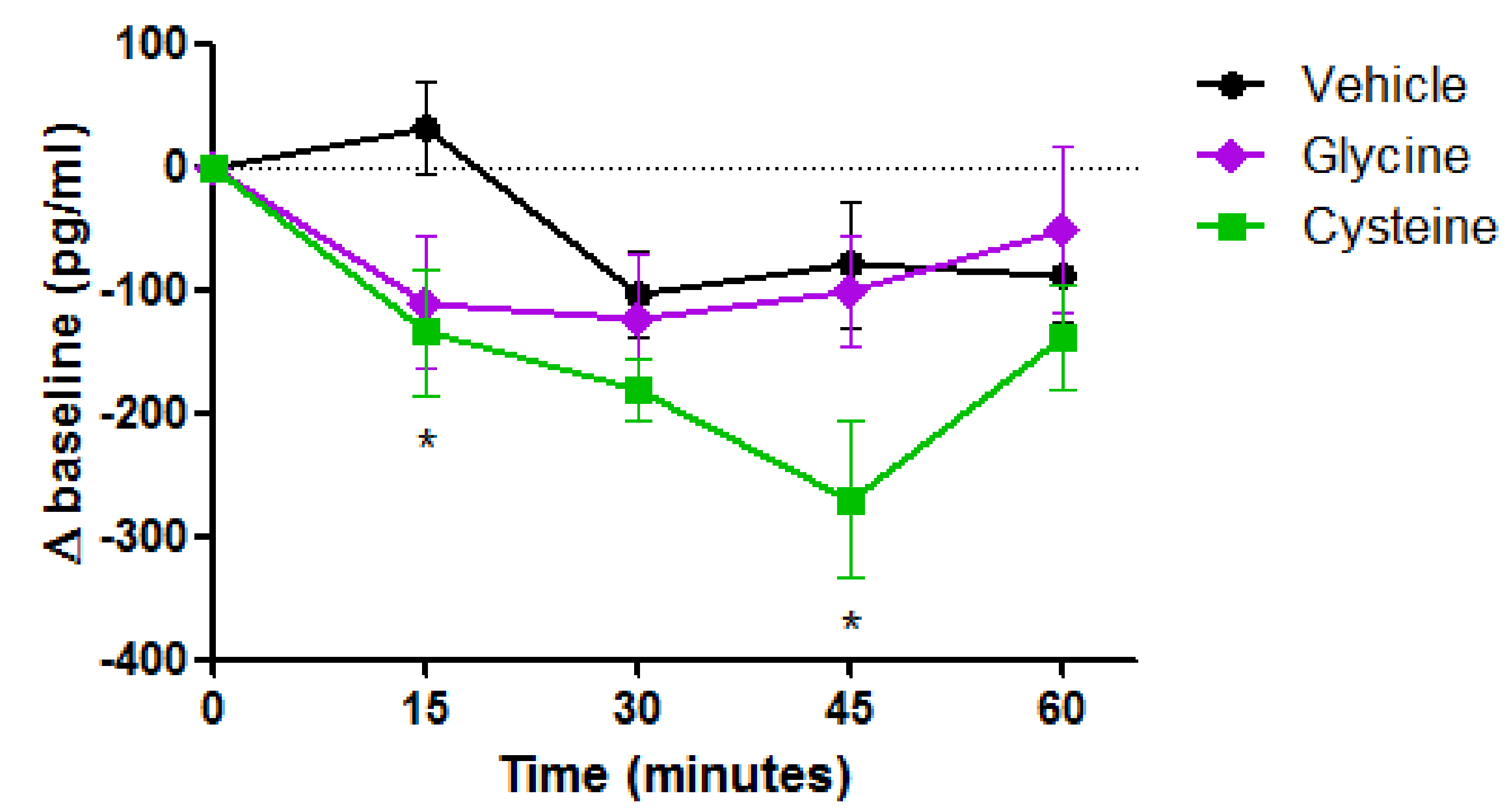

Figure 1. Change in plasma ghrelin following oral ingestion of vehicle, $0.07 \mathrm{~g} / \mathrm{kg}$ glycine, $0.07 \mathrm{~g} / \mathrm{kg} \mathrm{L-cysteine}(\mathrm{n}=7){ }^{*} \mathrm{p}<0.05$

\section{L-cysteine suppresses appetite}
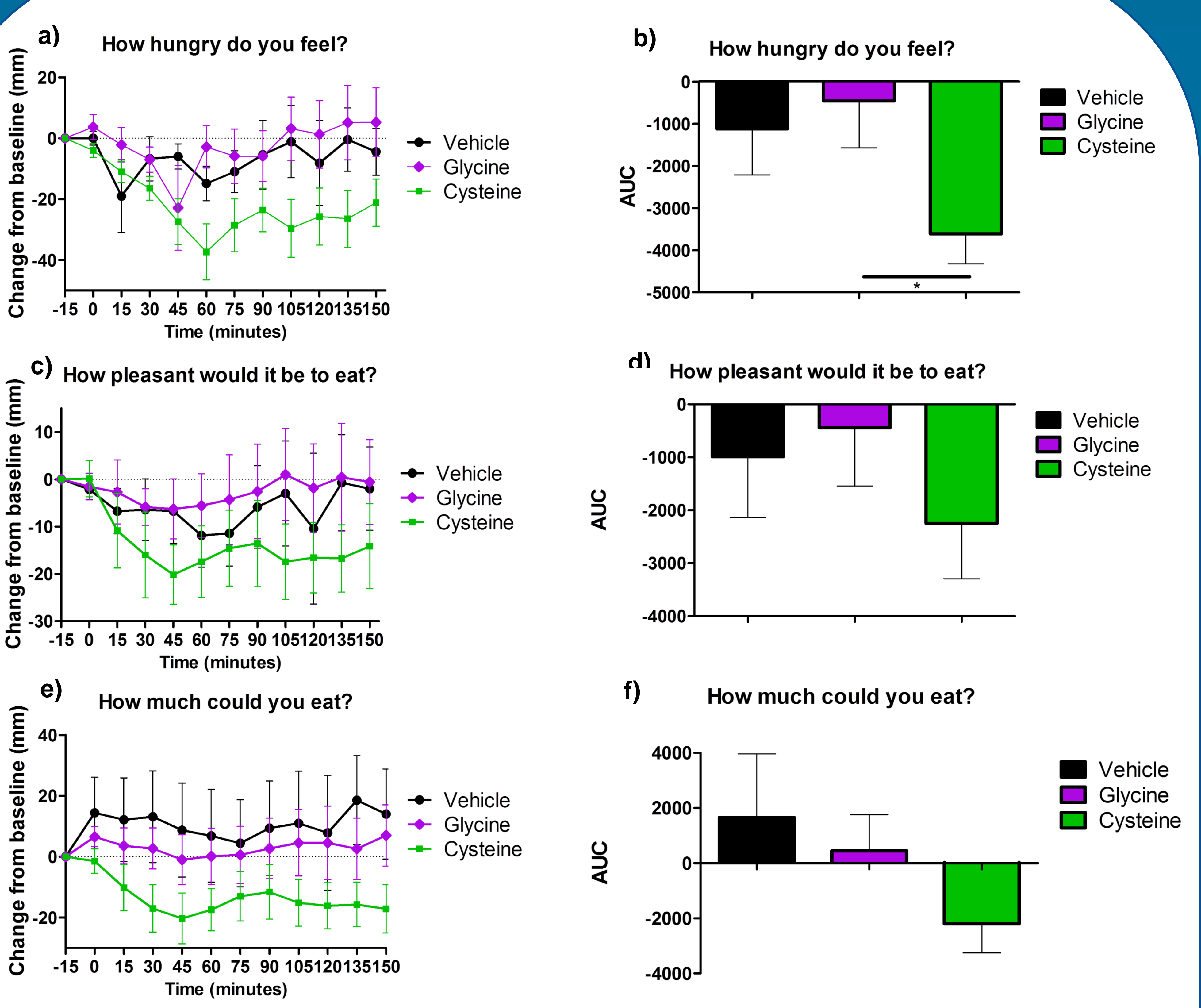

f) How much could you eat?

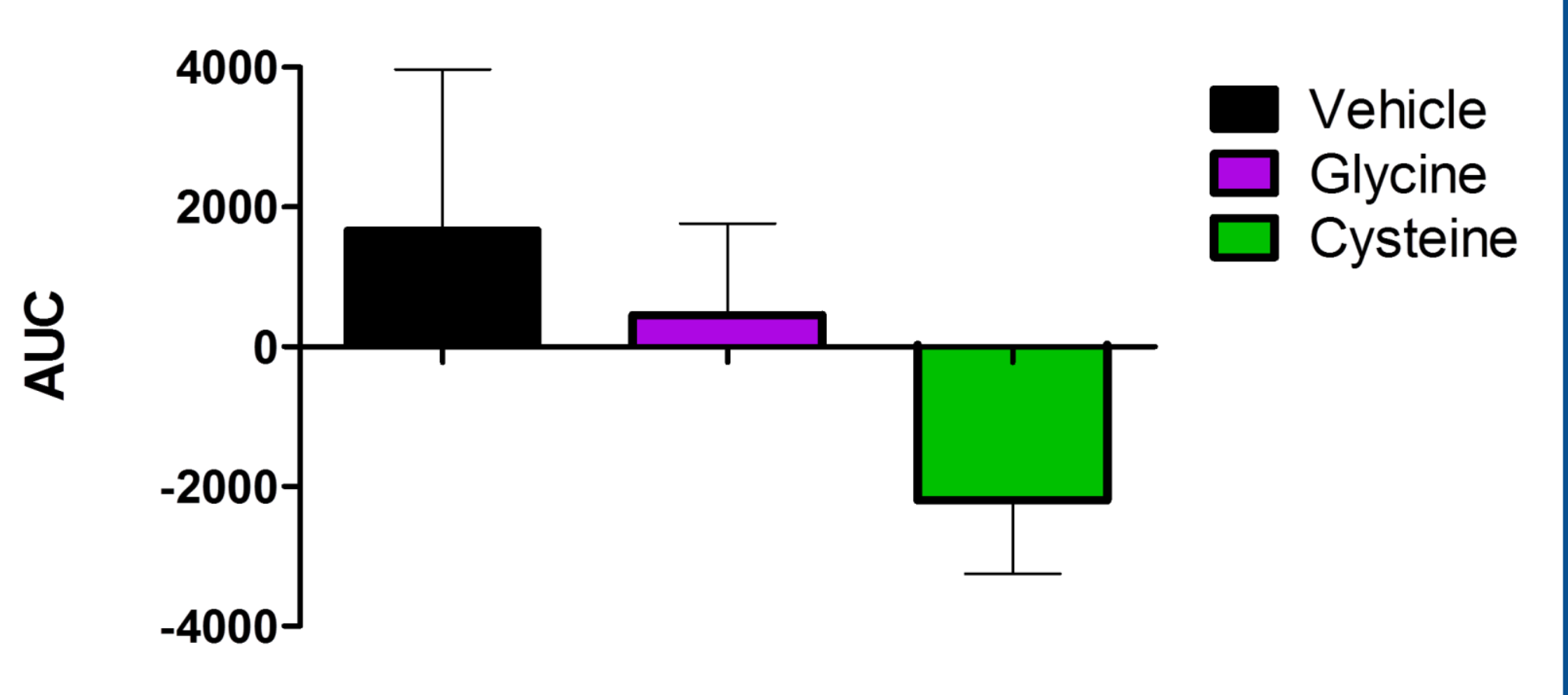

Figure 2. Visual analogue scales and area under the curve following ingestion of vehicle, $0.07 \mathrm{~g} / \mathrm{kg} \mathrm{L-cysteine} \mathrm{or} 0.07 \mathrm{~g} / \mathrm{kg}$ glycine $(n=7){ }^{*} \mathrm{p}<0.05$

\section{Discussion}

- L-cysteine can pharmacologically reduce appetite

- Currently unclear whether this pharmacological effect represents a physiological role

- At physiological concentrations, cysteine, may act in concert with other Lamino acids, to mediate protein-induced satiety.

- The mechanism by which cysteine reduces appetite remains unclear, but may involve a suppression of ghrelin release.

- Pre-clinical studies using knockout mice or pharmacological antagonists are required to determine the receptors involved in protein and amino acidinduced satiety, and the mechanisms by which this process occurs.

\section{References}

JEAN, C ROME, $S$, MATHE, $V$, et al. 2001. Metabolic evidence for adaptation to a high protein diet in IEAN, J Nutr. 131, $91-9$

ats. J Nutr, 131, 91-9 the regulation of food intake in monkeys. Am J Clin Nutr, 52, 320-5 M. enriched meal replacements in subjects with the metabolic syndrome. Diabetes Metab Res Rev, 26, 393-

${ }^{4}$ CHRISTIANSEN, B., HANSEN, K. B., WELLENDORPH, P. \& BRAUNER-OSBORNE, H. 2007. Pharmacological characterization of mouse GPRC6A, an L-alpha-amino-acid receptor modulated by divalent cations. Br JPharmacol, 150, 798-807

${ }^{5}$ NELSON, G., CHANDRASHEKAR, J., HOON, M. A., FENG, L, ZHAO, G RYBA N. J. \& ZUKER, C. S. 2002. An amino-acid taste receptor. Nature, 416, 199-202

CONIGRAVE, A. D., QUINN, S.J. \& BROWN, E. M. 2000 L-amino acid sensing by the extracellular Ca2+-sensing receptor. Proc Natl Acad Sci U S A, 97, 4814-9

VELDHORST, M. A., NIEUWENHUIZEN, A. G., HOCHSTENBACH-WAELEN, A. VAN VUGHT, A. J WESTERTERP, K. R., ENGELEN, M. P., BRUMMER, R. J., DEUTZ, N. E. \& WESTERTERP-PLANTENGA M. S. 2009. Dose-dependent satiating effect of whey relative to casein or soy. Physiol Behav, 96, 675-82 \&OWEN, J., NOAKES, M. \& CLIFTON, P. M. 2007. Appelle hormones and energy intake in obese men after consumption of fructose, glucose and whey protein beverages. Int J Obes (Lond), 31, 1696-703 